\title{
Design of a Multi-Functional Wheelchair Based Fuzzy Analytical Hierarchy Process
}

\author{
Muhammad Nur Iksan a,*, Anita Susilawati a \\ a) Mechanical Engineering Department, Universitas Riau, Indonesia \\ *Corresponding author: muhammad.nur3722@student.unri.ac.id
}

\section{Paper History}

Received: 06-January-2021

Received in revised form: 06-March-2021

Accepted: 30-March-2021

\begin{abstract}
Wheelchairs are tools for humans who experience illness, disabilities, and injuries that cause walking difficulties. There are many types of wheelchairs on the market, while wheelchairs that function to help users defecate flexibly have not been widely sold in the market. Therefore, it is necessary to develop a flexible and multifunctional wheelchair that can assist the users in carrying out their activities. This study aims to develop a design of the multifunctional wheelchair. The designing of multifunctional wheelchair based the FAHP (Fuzzy Analytical Hierarchy Process) method. The use of the FAHP was to select the optimal design and selection of the best alternatives among wheelchair's indicators of design proposed. The results of calculation of weight values for wheelchair design were obtained a percentage of alternative 1 of $48 \%$ and alternative 2 of $52 \%$.
\end{abstract}

KEY WORDS: Fuzzy Analytical Hierarchy Process, FAHP, Multifunctional Wheelchair.

\subsection{INTRODUCTION}

Various types and functions of wheelchairs are continuously being developed to meet the activity needs of its users (consumers). Subsequence, it is necessary to innovation a product design for flexible, multifunctional wheelchair that can help wheelchair users carry out activities [1]. The product design starts from the many needs for the product, which are identified by market demand [2]. The final product goes through two main processes from concept creation to finished product. The two processes are the product design and development process.
Recently, several companies are facing pressure from innovation to develop products with lower prices and good quality [2]. In an effort to improve the quality and quantity of a product to meet the needs and satisfy consumers, the product design must utilize the means of production, workers, and raw materials as much as possible, so that the resulting product will be better [3]. However, in designing a product may occurred the problems, which usually more subtle and the process requires repetition [4]. There are some methods may be used to meet the design criteria, such as the Analytical Hierarchy Process, Fuzzy Analytical Hierarchy Process and others. The analytical hierarchy process method, abbreviated as AHP, is a method used to make a decision using factors of logic, perception, knowledge, and experience. The AHP method has been developed by a mathematician from the University of Pittsburgh in the United States named Thomas L. Saaty, in the 1970s [5-6]. Analytical hierarchy process method is used for decision-making in solving a problem [7]. The analytical hierarchy process method also has uncertainties, which results in weaknesses in the use of this method. The FAHP method is a method that overcomes the weaknesses and developments of the analytical hierarchy process method [5-6]. Decision making is a process that is always encountered in practical life [8]. So, the FAHP is chosen in this paper to development the design process for multifunctional wheelchair.

The manual wheelchairs at this time only have a function as a tool to help carry out activities to one place or another. According the research was conducted by [9], it aims to identify the needs of people with paraplegia for wheelchair products, and to design a wheelchair that suits to the needs of paraplegics. Based on [9], the consumers needs for the wheelchair such as a lightweight, non-slip wheels, easy to turn, easy to find spare parts, easy to find frames, stable, comfortable to use, easy to use and safety. The wheelchair designed by [9] has the function of defecating, but the existing design only has a potty, while the function for defecating directly on the toilet seat does not exist. In this paper objective is to improve the design a wheelchair in [9] using the FAHP method. In a multifunctional wheelchair, users can use it in their daily activities at the same time to make it easier for users to defecate. 


\subsection{METODOLOGI}

\subsection{Data Collection of Consumer Needs}

The collecting data on consumer needs is the stage of data on the needs for multifunctional wheelchair products to be designed. Data collection on consumer needs has at least more than 10 assessors [10]. The collection of consumer data was taken in the Province of Riau. The assessment was spread to the wheelchair users, nurses or families of wheelchair users. The design of questionnaire consists of 6 indicators, namely:

a. Design indicators

- The wheelchair size fits the toilet seat

- Potty to defecate can be assembled

b. Flexible indicators

- Easy to operate

- Easy to assembling

c. Usability indicators

- Easy to use

- Can be used on the toilet seat

d. Material indicators

- Easy to clean

- Made of strong material

e. Safety indicators

- Has a tire cover

- Has a two-point seat belt

f. Aesthetic indicators

- Cylindrical frame shape

- Box frame shape

This data assessment employs a scale of 1 to 5 , that is:

$\begin{array}{ll}\mathrm{a}=\text { liked very much } & \text { (value 5) } \\ \mathrm{b}=\text { preferred } & \text { (value } 4) \\ \mathrm{c}=\text { ordinary } & \text { (value 3) } \\ \mathrm{d}=\text { less favorable } & \text { (value 2) } \\ \mathrm{e}=\text { disliked } & \text { (value 1) }\end{array}$

The assessment calculation formula [11]:

Percentage $=($ total score $) /($ ideal score $) \times 100 \%$

Where:

Total score $=$ scale 1 to 5

Ideal score $=$ highest value $\mathrm{x}$ number of respondents

\subsection{Decision Based FAHP}

This stage is to choose a decisions using FAHP (Fuzzy Analytical Hierarchy Process). In this research, the wheelchair to be developed is a manual wheelchair that is commonly used by many people. A manual wheelchair (standard) only functions as a walker. So, the innovation of this multifunctional wheelchair can be used for defecation as well. In this study, a wheelchair standard was developed using the FAHP method for selecting materials, and seating designs. The users can feel the comfort and safety of using this proposed wheelchair. The steps in the fuzzy-AHP method to select the optimal design can be seen in Figure 1.

1. Determine the Weights Criteria

Determine the weight criteria of the wheelchair to be designed and to obtain a level of importance in the selection by comparing one interest with another, can be seen in Table 1.

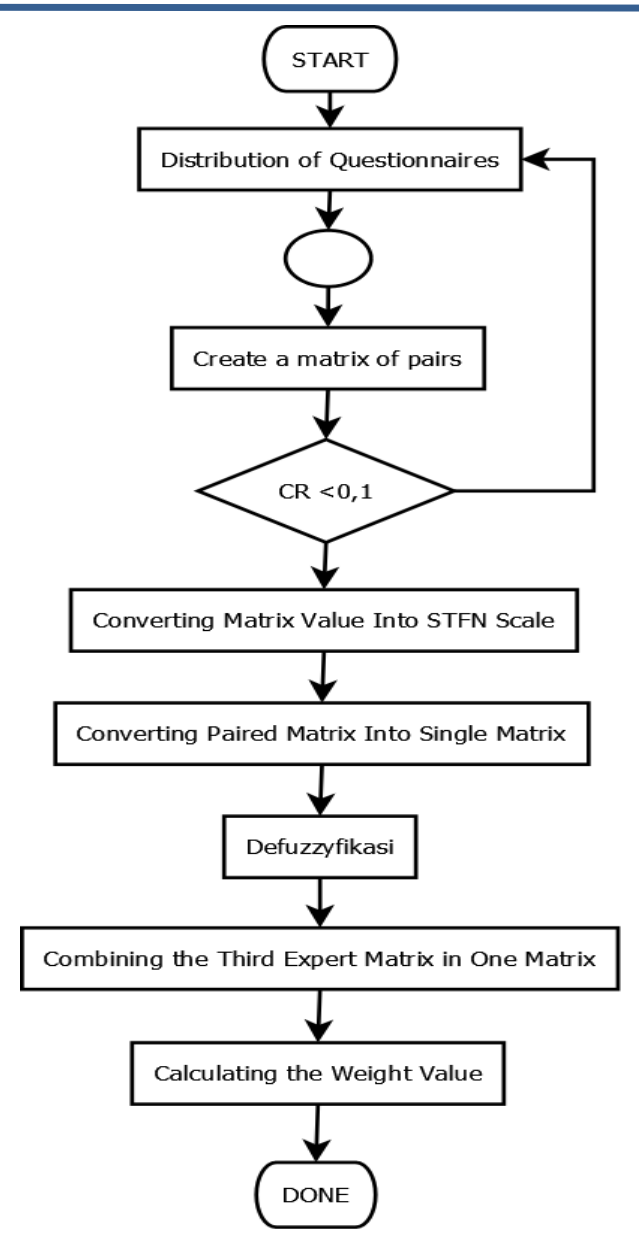

Figure 1: Fuzzy AHP Flowchart to Select the Optimal Wheelchair Design

Table 1: Weights Criteria of the AHP Method [12]

\begin{tabular}{|c|c|c|}
\hline Intensity & Information & Explanation \\
\hline 1 & $\begin{array}{l}\text { The two elements } \\
\text { are equally } \\
\text { important }\end{array}$ & $\begin{array}{l}\text { Two elements have the } \\
\text { same great influence on } \\
\text { goals }\end{array}$ \\
\hline 3 & $\begin{array}{l}\text { One element is } \\
\text { slightly more } \\
\text { important than the } \\
\text { other }\end{array}$ & $\begin{array}{l}\text { Experience and judgment } \\
\text { support one element more } \\
\text { than another }\end{array}$ \\
\hline 5 & $\begin{array}{l}\text { One element is } \\
\text { more important } \\
\text { than the other }\end{array}$ & $\begin{array}{l}\text { Experience and judgment } \\
\text { strongly support one } \\
\text { element over another }\end{array}$ \\
\hline 7 & $\begin{array}{l}\text { One element is } \\
\text { absolutely more } \\
\text { important than the } \\
\text { other }\end{array}$ & $\begin{array}{l}\text { Experience and assessment } \\
\text { are strongly supported and } \\
\text { dominant seen in practice }\end{array}$ \\
\hline 9 & $\begin{array}{l}\text { One absolute } \\
\text { element is } \\
\text { preferred over } \\
\text { other elements }\end{array}$ & $\begin{array}{l}\text { One element is preferred } \\
\text { over the comparison } \\
\text { element }\end{array}$ \\
\hline $2,4,6,8$ & $\begin{array}{l}\text { The values } \\
\text { between two } \\
\text { adjacent } \\
\text { consideration } \\
\text { values }\end{array}$ & $\begin{array}{l}\text { These values are given } \\
\text { when there are two } \\
\text { compromises between the } \\
\text { two options }\end{array}$ \\
\hline
\end{tabular}


(C) 2012 ISOMAse, All rights reserved

2. Create a Hierarchical Structure

The construction of hierarchical structure of the multifunctional wheelchair design can be seen in Figure 2 .

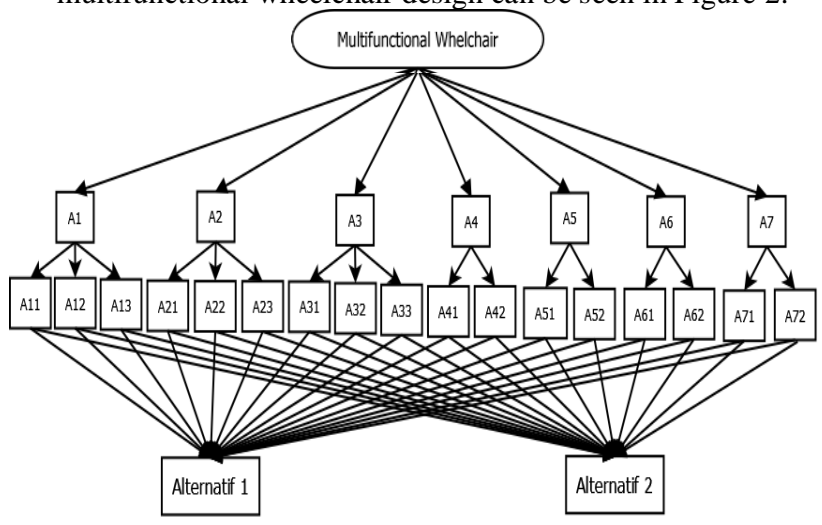

Figure 2: Hierarchy Structure for Multifunctional Wheelchairs

The hierarchical structure in Figure 2: the first level is a parameter of a multifunctional wheelchair, namely: A1. seat; A2. design components for defecation; A3. wheels; A4. wheelchair displacement; A5. design for defecation; A6. frame material; A7. Safety. The second level of the hierarchical structure in Figure 2 shows the sub-parameters of the wheelchair. Then, it was construct the questionnaire to obtain a level of importance in the selection of product designs to be made by comparing one interest with another.

3. Distribute the questionnaire

The distribution of the questionnaire is intended for experts, namely people who are experts in their fields to select a criterion and assign a weight to the criterion. This case, it gave to the 3 people who were experts in them fields of design and manufacturing/production.

4. Create a pairwise comparison matrix

A pair-wise comparison matrix was filled with values based on weights and criteria.

Table 2: Pair-wise Comparison Matrix [13]

\begin{tabular}{ccccc}
\hline & $\mathrm{A}_{1}$ & $\mathrm{~A}_{2}$ & $\ldots$ & $\mathrm{A}_{\mathrm{IJ}}$ \\
\hline $\mathrm{A}_{1}$ & 1 & $\mathrm{~A}_{12}$ & $\ldots$ & $\mathrm{A}_{1, \mathrm{IJ}}$ \\
$\mathrm{A}_{2}$ & $\mathrm{~A}_{21}$ & 1 & $\ldots$ & $\mathrm{A}_{2, \mathrm{IJ}}$ \\
$\ldots$ & $\ldots$ & $\ldots$ & $\ldots$ & $\ldots$ \\
$\mathrm{A}_{\mathrm{IJ}}$ & $\mathrm{A}_{\mathrm{IJ}, 1}$ & $\mathrm{~A}_{\mathrm{J}, 2}$ & $\ldots$ & 1 \\
\hline
\end{tabular}

5. Determining of Consistency Ratio (CR) value

The $\mathrm{CR}$ is a test to assess the consistency of the answers to the questionnaire from the expert, if the CR value is > 0.1 then the distribution of the questionnaires is repeated. The competency test is carried out with the following equation [14]:

$$
\begin{aligned}
& C I=\frac{\lambda \max -n}{n-1} \\
& \lambda \max =\frac{\text { priority weights }}{\text { criterion weights }} \\
& C R=\frac{C I}{R I}
\end{aligned}
$$

Where:

$$
\begin{aligned}
& C R=\text { Consistency Ratio } \\
& C I=\text { Consistency Index } \\
& R I=\text { Random Consistency Index } \\
& N=\text { Number of Elements }
\end{aligned}
$$

The ratio index (RI) [12] can be seen in Table 3 .

Table 3: Ratio Index

\begin{tabular}{cccccccccc}
\hline $\mathrm{n}$ & 1 & 2 & 3 & 4 & 5 & 6 & 7 & 8 & 9 \\
\hline $\mathrm{RI}$ & 0 & 0 & 0,85 & 0,9 & 1,12 & 1,24 & 1,32 & 1,4 & 1,45 \\
\hline
\end{tabular}

6. Paired matrix values are converted into the STFN scale The conversion of pair-wise comparison matrix into the TFN scale [15] is shown in Table 4.

Table 4: STFN (Standard Trapezoidal Fuzzy Number) [15]

\begin{tabular}{ccc}
\hline Precise & STFN & Linguistic variable \\
score & & Equally important \\
1 & $(0,0,5,1,5,2)$ & Weakly important \\
3 & $(2,2,5,3,5,4)$ & Essentially important \\
5 & $(4,4,5,5,5,6)$ & Very strongly important \\
7 & $(6,6,5,7,5,8)$ & Absolutely important \\
9 & $(8,8,5,9,5,10)$ & Value between two \\
$2,4,6,8$ & $(\mathrm{x}-1, \mathrm{x}-0,5, \mathrm{x}+0,5$, & levels \\
\hline
\end{tabular}

7. Paired matrix is converted into a single matrix

The paired matrix conversion is converted into a single matrix with equation [11]:

$$
\begin{aligned}
& d\left(\widetilde{b_{0}}, \widetilde{b 2}\right)=\left[b_{2}^{2}+b_{3}^{2}+\frac{\left(b_{2}-b_{1}\right)^{2}}{3}+\frac{\left(b_{4}-b_{3}\right)^{2}}{3}-\right. \\
& \left.b_{2}\left(b_{2}-b_{1}\right)+b_{3}\left(b_{4}-b_{3}\right)\right]^{1 / 2}
\end{aligned}
$$

8. Defuzzification

The defuzzification is a fuzzy set value that will be converted into a firm set value. The defuzzification steps (Bij) $[11,16]$ are as follows:

a) Calculating the value of Wi with the equation:

$W i=\frac{S(B i)}{\sum_{t=1}^{n}(B t)}$

if $\mathrm{S}(\mathrm{Bi})=0$, then $\mathrm{Wi}=1 / \mathrm{n}, \mathrm{n}=$ number of respondents.

if $\mathrm{S}(\mathrm{Bi}) \neq 0$, then

$W i=\frac{S(B i)}{\sum_{t=1}^{n}(B t)}$

Where $\mathrm{S}(\mathrm{Bi})$ is the aggregate value of a single matrix for each expert, it can be obtained by the following equation:

$$
\begin{aligned}
& S(B i)=\sum_{t=1}^{n} d\left(\widetilde{B_{t}}, \widetilde{B}_{i}\right) \\
& d\left(\widetilde{b_{t}}, \tilde{b}_{i}\right)=d\left(\widetilde{B_{t}}, \widetilde{B}_{0}\right)-d\left(\widetilde{B_{l}}, \tilde{B}_{0}\right)
\end{aligned}
$$

b) Combining the values of the three experts into one matrix using the following equation:

$$
m_{i j}=\left(W i A \cdot A_{11}+W i B \cdot B_{11}+W i C \cdot C_{11}\right)
$$


c) Defuzzification value is calculated by the equation:

$$
m_{i j}=\left[\frac{m_{11}+2 m_{12}+2 m_{13}+m_{14}}{6}\right]
$$

9. Calculating the value of weight (W)

The value of weight $(\mathrm{W})$ is the weight on each criterion and can be obtained using the following equation [11]:

$$
W=\frac{\text { Average }}{\text { the average number of rows }}
$$

10. Selection of the best alternative decision is made after the final value obtained from each matrix. Therefore, based on the final value received and the criteria for a multifunctional wheelchair can be decided.

\subsection{RESULT AND DISCUSSION}

\subsection{Results}

1) Result of the Consumer Needs

The result of the assessment of consumer needs for wheelchair is depicted in Figure 3. In Figure 3 is depicted the highest percentage of each parameter of the material aspect, which was easy to clean and made of strong materials. Both of them have the same value of $86.67 \%$. The lowest percentage value is showed in the aesthetic aspect of the cylinder frame shape with a percentage value of $78.33 \%$.

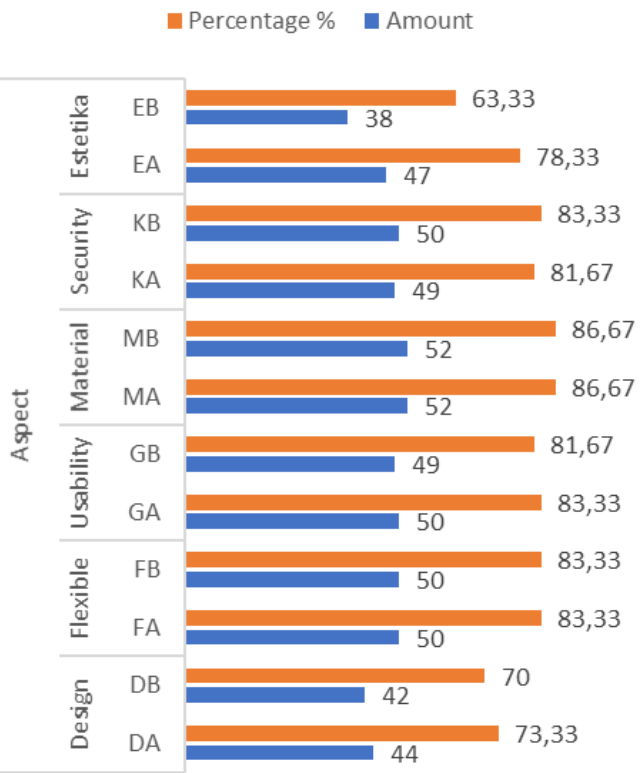

Figure 3: The Values Results of Consumer Needs Parameters

2. Wheel Chair Design

Based the percentage values of the customers need in step 1, the parameter for wheelchair design i.e. wheelchair size fits to toilet seat, easy to use, easy to assemble, easy to clean, made of strong material, has a two-point seat belt and cylindrical frame shape. Then, there were two wheelchair design alternatives, namely: alternative 1 (Figure 4) and alternative 2 (Figure 5). The alternative design 1 was a seat cushion material in the form of foam and covered with cloth, the material for the pot that was plastic, the shape of the pot was curved downward, and potty installation used the clamping system. The alternative design 2 , the seat cushion material was foam and covered with synthetic leather, the material of the pot was stainless steel, the shape of the pot was flat down and the installation of the potty was by sliding system.

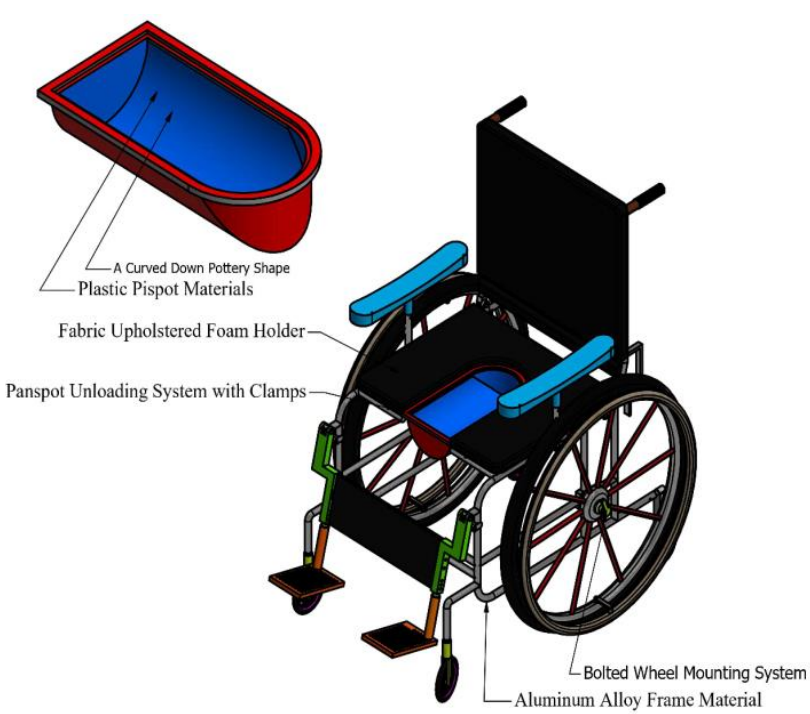

Figure 4: Alternative Wheelchairs 1

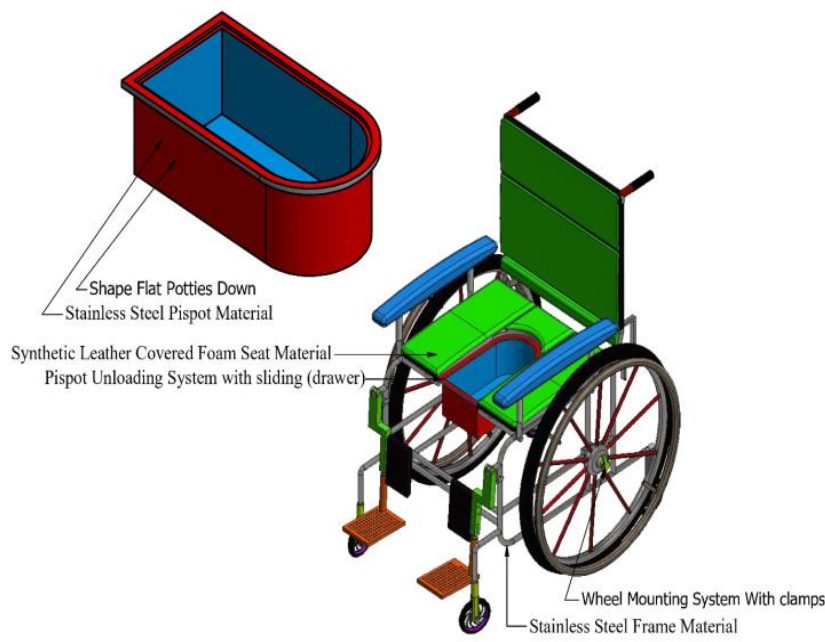

Figure 5: Alternative Wheelchairs 2

3. The Fuzzy-AHP Calculation Results

The hierarchical structure of the multifunctional wheelchair consists of 7 parameters, namely: A. Seat, B. Design components for defecation, C. Wheels, D. Wheelchair displacement, E. Design for defecation, F. Frame material and G. Safety. The results of data processing from the questionnaire addressed to each expert priority of weights can be seen in Table 5. The values of weight parameters of wheelchair design can be seen in Table 6. In Table 7 is shown the weight values of sub-parameter of wheelchair design. 


\begin{tabular}{cccc}
\hline \multicolumn{4}{c}{ Table 5: Expert Priority of Weights } \\
\hline Parameters & $\begin{array}{c}\text { Weight } \\
\text { values by } \\
\text { expert 1 }\end{array}$ & $\begin{array}{c}\text { Weight } \\
\text { values by } \\
\text { expert 2 }\end{array}$ & $\begin{array}{c}\text { Weight } \\
\text { values by } \\
\text { expert 2 }\end{array}$ \\
\hline A & 0,09 & 0,26 & 0,17 \\
B & 0,28 & 0,09 & 0,06 \\
C & 0,07 & 0,25 & 0,17 \\
D & 0,15 & 0,06 & 0,19 \\
E & 0,22 & 0,09 & 0,07 \\
F & 0,05 & 0,11 & 0,12 \\
G & 0,12 & 0,15 & 0,23 \\
\hline
\end{tabular}

Table 6: The Weight Parameter Values

\begin{tabular}{cc}
\hline Parameter & Weight \\
\hline Seat & 0,172 \\
Design components for defecation & 0,165 \\
Wheels & 0,125 \\
wheelchair displacement & 0,135 \\
Design for defecation & 0,152 \\
Frame of material & 0,094 \\
Safety & 0,155 \\
\hline
\end{tabular}

Table 7: The Weight of Sub-Parameter Values

\begin{tabular}{|c|c|}
\hline Sub Parameter & $\begin{array}{c}\text { Weight of } \\
\text { Sub- } \\
\text { Parameter }\end{array}$ \\
\hline \multicolumn{2}{|l|}{ Seat } \\
\hline Seating size & 0,631 \\
\hline Mount material & 0,230 \\
\hline Holder thickness & 0,138 \\
\hline \multicolumn{2}{|l|}{ Design components for defecate } \\
\hline A potty form & 0,364 \\
\hline A potty depth & 0,282 \\
\hline A potty material & 0,352 \\
\hline \multicolumn{2}{|l|}{ Wheels } \\
\hline Wheel type & 0,194 \\
\hline Wheel size & 0,443 \\
\hline Wheel unloading system & 0,361 \\
\hline \multicolumn{2}{|l|}{ Wheelchair displacement } \\
\hline $\begin{array}{l}\text { Ease of positioning the wheelchair on the } \\
\text { toilet seat }\end{array}$ & 0,790 \\
\hline Ease of transporting a wheelchair & 0,209 \\
\hline \multicolumn{2}{|l|}{ Design for defecation } \\
\hline A potty to defecate used unloading system & 0,739 \\
\hline Can be used on toilet seats & 0,261 \\
\hline \multicolumn{2}{|l|}{ Material } \\
\hline Aluminum alloy & 0,468 \\
\hline Stainless steel & 0,531 \\
\hline \multicolumn{2}{|l|}{ Safety } \\
\hline Wheelchairs have wheel cover & 0,202 \\
\hline Wheelchairs have seat belts & 0,794 \\
\hline
\end{tabular}

Table 8: Percentage of Alternative Wheelchairs Design

\begin{tabular}{ccc}
\hline No & $\begin{array}{c}\text { Alternatives to } \\
\text { wheelchair design }\end{array}$ & Percentage \\
\hline 1 & Alternative 1 & $48 \%$ \\
2 & Alternative 2 & $52 \%$ \\
\hline
\end{tabular}

\subsection{Discussion}

The wheelchair proposed design is determined from the assessment of the highest alternative weight value. The values of weight parameter can be seen in Table 6. The highest weight value is the seat parameter with a value of 0.172 . The lowest value is the frame material parameter with a value of 0.094 . Therefore, the standard wheelchair would be modified the seat parameter.

After obtaining the weight parameter value, then the subparameter weight value is calculated. From the weight value results in Table 7, in the seat parameter, which the highest sub-parameter weight value on the seat size, with a value of 0.631 . The lowest sub-parameter of weight value is the seat thickness with a value of 0.138 . In the parameter of the design component for defecating, the highest weight value is the shape of the potty with a value of 0.364 and the lowest in the potty depth with a value of 0.282 . In the wheel parameter, the highest weight value is wheel size with a value of 0.443 while the lowest sub-parameter value is the type of wheel with a value of 0.194 . In the parameter of the highest weight value, wheelchair displacement is the ease of positioning the wheelchair to the toilet seat with a value of 0.790 while transporting a wheelchair with a value of 0.209. In the design parameters for defecating (defecating) the highest weight value is the installation of a potty unloading system with a value of 0.739 and the lowest with a value of 0.261 . In the material parameter, the highest weight value is stainless steel with a value of 0.531 , while aluminum alloy with a value of 0.468 . The safety parameter, the highest weight value is a wheelchair has a seat belt with a value of 0.794 , while on the tire cover with a value of 0.202 .

The final percentage value of wheelchair alternatives, which is the final value of each alternative parameter and wheelchair sub-parameter, can be seen in Table 8 . The highest alternative percentage is alternative 2 with a percentage of $52 \%$, which is influenced by the seat parameter with the seat size sub-parameter. The alternative 1 is the lowest with a percentage value of $48 \%$. Based on the results of each parameter value and sub-parameter in the comparison between alternative 1 and alternative 2 , is combined to improve the existing design. The highest sub-parameter value for both alternatives is adopted to make the optimal wheelchair design. The result of proposed wheelchair based FAHP method is illustrated in Figure 9.

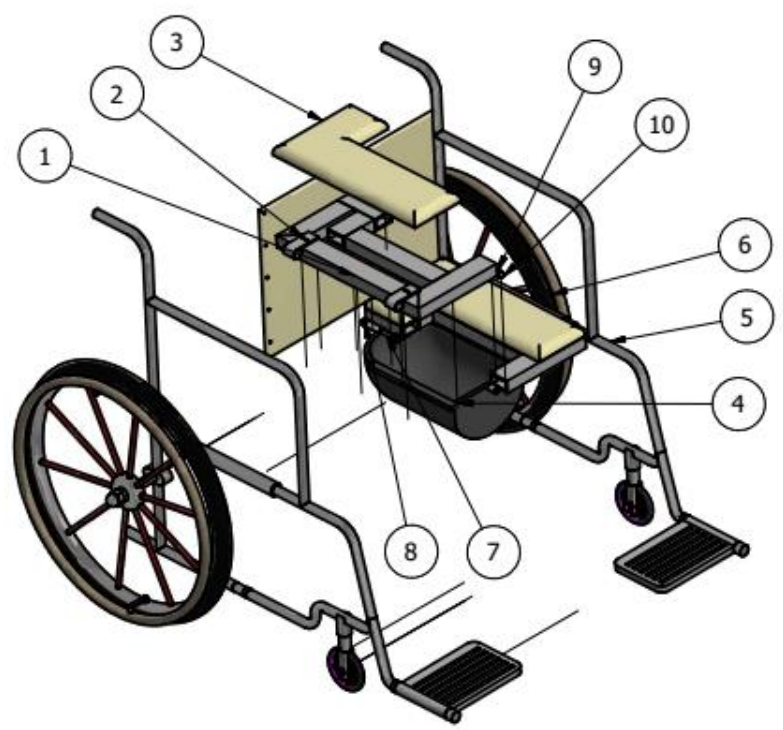

Figure 9: The Result of Wheelchair Design based FAHP Method 


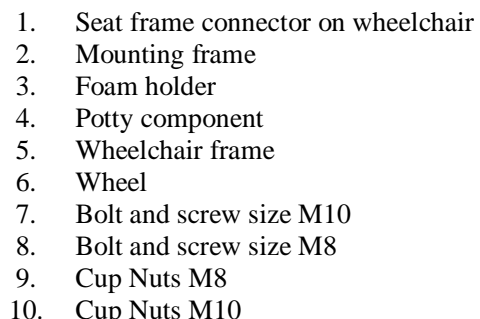

\subsection{CONCLUSION}

The designing of multifunctional wheelchair based the FAHP (Fuzzy Analytical Hierarchy Process) method is proposed in this paper. The FAHP method can be implemented in determining the optimal multifunctional wheelchair design. The steps design in this paper are to create a hierarchical structure, determining the weighted value parameters, distributing questionnaires, making pair-wise comparison matrices, determining the $\mathrm{CR}$ value of each expert, changing the matrix value into the STFN scale, changing the paired matrix to single matrix, calculate the defuzzification value, calculate the weight value. The result revealed the highest weight value is the seat parameter value of 0.172 and alternative 2 design. Finally, the highest sub-parameters value for both alternatives is adopted to make the optimal wheelchair design.

\subsection{REFERENCE}

[1] Syam, R. and Mustari (2011). Rancang bangun kursi roda elektrik untuk kondisi naik turun tanjakan, Jurnal Mekanikal, Vol.2, No.2, pp: 147-155.

[2] Patil, H.M., Saurabh, S.S. and Nitin, N.G. (2017). Product design and development: phases and approach, International Journal of Engineering Research \& Technology, Vol.6, No.7.

[3] Dewi, D.C., Handayani, C. and Prasetyo, I.H. (2019). Perancangan alat spinner ergonomis (study kasus pt. baasithu, floating storage and offloading petrostar, Jurnal Inovator, Vol. 2, No.1, pp: 11-15.

[4] Khandani, S. (2005). Engineering Design Process. Mechanical Engineering, Diablo Valley College in Pleasant Hill, California.
[5] Chang, D.Y. (1996). Applications of the extent analysis method on fuzzy AHP, European Journal of Operational Research, Vol.95, pp: 649-655.

[6] Elvenly, M. And Rahmadsyah (2014). Analisis metode fuzzy analytical hierarchy process (fahp) dalam menentukan posisi jabatan, TECHSI, Vol.4, No.1.

[7] Fajri, M, Rekyan, R.M.P. and Lailil, M. (2018). Implementasi metode fuzzy analytical hierarchy process (fahp) dalam penentuan peminatan di MAN 2 Serang, Jurnal Pengembangan Teknologi Informasi dan Ilmu Komputer Vol. 2, No.5, pp: 2109-2117.

[8] Nawal, S., Touria, H. and Faouzia, B. (2019). Implementation of the analytic hierarchy process for student profile analysis, International Journal of Emerging Technologies in Learning, Vol.14, No.15.

[9] Ilham, B. (2009). Perancangan kursi roda bagi penyandang paraplegia dengan metode quality function deployment ( $q f d$ ), Prosiding Seminar Nasional Tahunan Teknik Mesin (SNTTM) VIII, Universitas Diponegoro, Semarang 11-12 Agustus, pp: 346-356.

[10] Ulrich, K., Eppinger, D.T. and Steven, D. (2012). Product Design and Development. Fifth Edition, Mcgraw Hill.

[11] Rudiansyah, Yohanes and Susilawati, A. (2019). Pengembangan desain tongkat penjepit multifungsi menggunakan metode fuzzy analytical hierarchy process (fahp), Jom FTEKNIK, Vol.6, No.2, pp: 1-9.

[12] Saaty, T.L. (1990). How to make a decision: the analytical hierarchy process, European Journal of Operational Research, Vol.48, pp: 9-26.

[13] Kusrini (2007). Konsep dan Aplikasi System Pengambilan Keputusan. CV Andi Offset: Yogyakarta.

[14] Intan, A.N., Astri, T.P. Shofie, R.F, Senot, S. and Widi, H. (2017). Analytical hierarchy process (ahp), fuzzy ahp and TOPSIS for determining bridge maintenance priority scale in Banjarsari, Surakarta, International Journal of Science and Applied Science, Vol.2, No.1.

[15] Tasri, A. and Susilawati, A. (2014). Selection among renewable energy alternatifs based on a fuzzy analytical hierarchy process in Indonesia, Sustainable Energy Technologies and Assessments, Vol.7, pp: 34-44.

[16] Albeni, A. (2019). Penerapan metode fuzzy analytical hierarchy process untuk sistem penyeleksian bantuan rumah layak huni. Universitas Islam Negeri Sultan Syarif Kasim Riau, Pekanbaru. 